\title{
Health Education: Analysis of its Teaching in Undergraduate Nursing Courses
}

\author{
Alva Helena de Almeida ${ }^{1}$ \\ Cássia Baldini Soares²
}

From the perspective of Collective Health, this study aimed to analyze how the teaching of health education in undergraduate Nursing courses is processed contemporarily. The Educational Institutions were selected so as to represent the public and private sectors. The subjects, teachers responsible for developing the theme, were identified from the indications of the Coordinators of the Courses. An exploratory, descriptive, analytical, study with a qualitative approach was developed, which utilized documental analysis and a semi-structured interview based on a script, the analysis of which followed the steps of content analysis and identification of thematic nuclei. The results showed that the teaching developed remains largely linked with the biomedical preventive model and that the concepts of critical education and 'popular' educational practices are scarce, due to the deficient political education of the teachers, and more broadly, as a consequence of coping with an academic context of the implementation of the neoliberal ideas.

Descriptors: Health Education; Education, Nursing; Education, Higher; Faculty, Nursing.

\footnotetext{
${ }^{1}$ RN, Ph.D. in Sciences, Coordenadoria Regional de Saúde - Sudeste, Secretaria Municipal da Saúde de São Paulo, SP, Brazil. E-mail: alvahelena@uol.com.br.

${ }^{2}$ RN, Ph.D. in Education. Professor, Escola de Enfermagem, Universidade de São Paulo, SP, Brazil. E-mail: cassiaso@usp.br.
}

Corresponding Author:

Alva Helena de Almeida

Secretaria Municipal de Saúde de São Paulo. Coordenadoria Regional Saúde Sudeste

RH Desenvolvimento

Rua Padre Marchetti, 557

Bairro: Ipiranga

CEP: 04266-000 São Paulo, SP, Brasil

E-mail: alvahelena@uol.com.br 


\section{Educação em saúde: análise do ensino na graduação em enfermagem}

$\mathrm{Na}$ perspectiva da saúde coletiva, objetivou-se analisar como se processa, na contemporaneidade, o ensino de educação em saúde em cursos de graduação em Enfermagem. As instituições de ensino foram selecionadas de maneira a representar o setor público e o privado. Os sujeitos, docentes responsáveis pelo desenvolvimento da temática, foram identificados a partir da indicação dos coordenadores dos cursos. Desenvolveu-se pesquisa de caráter exploratório-descritivo-analítico, com abordagem qualitativa, que se utilizou de análise documental, de entrevista semiestruturada, com base em roteiro, cuja análise seguiu os passos da análise de conteúdo e identificação de núcleos temáticos. Os resultados evidenciaram que o ensino desenvolvido permanece majoritariamente vinculado ao modelo biomédico preventivo, e que as concepções de educação crítica e as práticas educativas 'populares' são escassas, devido à deficitária formação política dos docentes e, mais amplamente, como consequência do enfrentamento de contexto acadêmico de implementação do ideário neoliberal.

Descritores: Educação em Saúde; Educação em Enfermagem; Educação Superior; Docentes de Enfermagem.

\section{Educación en salud: análisis de la enseñanza en la graduación en enfermería}

En la perspectiva de la Salud Colectiva, se objetivó analizar como se procesa en la contemporaneidad la enseñanza de educación en salud en cursos de graduación en Enfermería. Las Instituciones de Enseñanza fueron seleccionadas de manera a representar al sector público y al privado. Los sujetos, docentes responsables por el desarrollo de la temática, fueron identificados a partir de la indicación de los Coordinadores de los Cursos. Se realizó una investigación de carácter exploratorio, descriptivo y analítico, de abordaje cualitativo, que se utilizó del análisis documental, de entrevista semiestructurada, con base en un guión, cuyo análisis siguió los pasos del análisis de contenido e identificación de núcleos temáticos. Los resultados evidenciaron que la enseñanza desarrollada permanece mayoritariamente vinculada al modelo biomédico preventivo, y que las concepciones de educación crítica y las prácticas educativas 'populares' son escasas, debido a la deficitaria formación política de los docentes, y más ampliamente, como consecuencia del enfrentamiento de un contexto académico de implementación del ideario neoliberal.

Descriptores: Educación en Salud; Educación en Enfermería; Educación Superior; Docentes de Enfermería.

\section{Introduction}

In the broad process of redemocratization of the Brazilian society, the institutionalization of the Brazilian National Health System (SUS) presented the Higher Education Institutions (HEIs) with one of their biggest challenges: the education of health workers according to the idea of this political project. Nursing, as an organized social segment of the health area, is articulated through the broad movement of the Brazilian Association of
Nursing (ABEn) involving educational institutions, service managers and unions regarding the proposed changes in the curricula of undergraduate courses in order to adapt them to the social and epidemiological reality of the country and to the political project under construction ${ }^{(1-2)}$. The proposal published in 1994 established as the minimum curriculum for undergraduate courses, except for a few alterations, became the reference proposition 
for the National Curriculum Guidelines (NCG) of the Undergraduate Course in Nursing, published by the National Education Council (NEC) in 2001. One of the alterations identified in this proposition referred to the exclusion of content related to the pedagogical education of nurses, restricting this to Licenciate courses. Thus, the preparation for educational practices appears to be implicit in the proposed professional profile, referred to as the integral health promotion nurse(3).

Education practices in health, in turn, have been discussed in the literature of this area since the beginning of last century, due to the close relationship between these actions and the health and economic policies implemented in Brazilian society, the service of a determined social control to ensure the interests of the dominant class $^{(4-6)}$. Some researchers ${ }^{(7-10)}$ have revealed their concern regarding the health education object in the teaching of nursing in studies that expressed, in short, the relationships between the educational practice developed by health professionals and the reality of the preparation of the nurse in the undergraduate courses to perform the role of educator. But what constitutes these educational actions? How they are being portrayed in the literature of the area?

The analysis of publications showed that health education, as a practice between subjects and mediators of health care, is of unquestionable relevance to the social practice of nursing. While such practices remain restricted to the biomedical approach, focused on the preventive aspects, a comprehension was evidenced that the peculiarities of the educational process requires specific education that is not inherent to the technical education of nurses. Furthermore, the need was recognized for the education of teachers to ensure both - educator and student - the educational function committed to social development. The evolution of the socio-political process in the national scenario, since the late 1980 s, was submitted to a context of changes of international economic policy, in which neoliberal ideas have determined modifications in the more general social issues. Among many, the role of the University in education has profoundly changed, both in the public and the private sectors?. One of the expressions of this logic is what has been called operational university: restriction of the institutional role to the attendance of the needs of the productive market ${ }^{(11)}$.

Although the organization of the nursing area has solidified important changes in the educational processes in response to the political project of the health sector, this process became secondary to the neoliberal ideas at the moment of the implementation of the NCG, through the incorporation of pragmatic and New School pedagogical principles, expressed primordially in the learn to learn and in the discourse of the competences ${ }^{(12)}$. In this social and scientific context, the so-called crisis of science has been critically interpreted as a result of the inadequacy of the predominant logic, the formal logic, faced with the constant development of science and with the complexity of the existing problems ${ }^{(13)}$. The necessity to explain the objective and subjective processes and the speed of the transformations proposed the adoption of dialectic reasoning in substitution of formal. Thus, the movement of curricular change in health and nursing in particular, has elaborated formative structures that contemplate the interdisciplinarity curriculum, as a strategy to deal with the teaching of the complex object that is the health-disease process (hdp), and thus, to respond to the broader issues of the sector, in particular to the principle of integrality of the system, as well as to meet the proposals of the NCG.

The recognition that the phenomenon of health and disease has specificities of a social process, which link with the other social processes and have a historical character, constitutes the context that feeds the theoretical root of Collective Health $(\mathrm{CH})$. Essentially critical and Marxist-inspired, $\mathrm{CH}$ emerged in Brazil in the 1970 s, in the context of the institutionalized public health crisis, constituting a theoretical and practical counterhegemonic field to cope with the needs and health problems of different social groups ${ }^{(14)}$. For $\mathrm{CH}$, nursing is a field of knowledge and practices in which professionals develop the work processes, in a specific, cooperative and interdisciplinary way, which comprise the process of production of health services. Among these processes, the process of healthcare work is highlighted, in which health education constitutes one of the necessary instruments ${ }^{(15)}$. Health education developed through the use of a critical emancipatory methodology, would contribute to the comprehension of the determinants of the hdp in accordance with popular interests ${ }^{(15-19)}$. In the context of $\mathrm{CH}$, Health education, approached from both the individual and the collective focus, has undergone modifications, incorporating concepts, expanding the practices referred to as behaviorist for approaches that configure the participation, the citizenship, the joining with social movements, in order to recover the political sense of the educational action ${ }^{(6)}$. Thus, the intentionality is reaffirmed of human action faced with the solidification of a previously idealized given project, which, mediated by educational activity, will result in a reiterative or 
creative praxis. The different levels of praxis stem from the degree of consciousness revealed by the subject in a practical process and the degree of creation shown by the product of its activity ${ }^{(16)}$.

The following assumptions of this study were thus established: the influence of theoretical frameworks and the complexity of the practical proposals for the field of $\mathrm{CH}$, as well as the participation of nursing in the discussion regarding the importance of interdisciplinarity and of other theoretical and methodological advances, grounded in dialectical perspective, regarding the production of knowledge and committed to the directives of the political project of the SUS, constitute favorable conditions for the development of non-traditional educational practices, consistent with these references and with the proposed care changes. Therefore, the general aim was to analyze how the teaching of health education in undergraduate Nursing courses in the State of São Paulo is processed contemporarily.

\section{Methodology}

The reconstructed social context has proved to be changeable, contradictory and strained by the social forces that represent, on one hand, a conservative scenario and, on the other, the changes, the disruptions in favor of a new project aimed at combating inequalities. Within this restless context act the agents of the social practices of health, who are routinely pressured by the turbulence of the established relationships in the work itself, by the concepts of society, of health and of education that guide their own practices, from the perspective of changes or of maintenance and reproduction of the structure and of the dynamic that conform to the social structure. Given this, it was decided to favor the apprehension of the object - the teaching of the health education thematic in the undergraduate nursing courses - through the use of a qualitative approach, because it "considers the context of the social phenomenon being studied, [...] and the essential and accidental aspects sought to be uncovered"(17).

The health education process as a social phenomenon resulting from the intentionality of the subjects, involves assumptions of the educator, placement of the undergraduate student, consequences in their education and in the professional practice involving the population. It was from this point, which is known as the political field, in the condition of subject implicated in the phenomenon, which sought the interpretation of this complex, interfaceted, reality drawing upon the potentiality of qualitative research known to "be able to incorporate the meaning and the intentionality as inherent to the actors, and to the social structures, as significant human constructions"(18). Besides the qualitative focus that makes the implications explicit between the subject and the object of knowledge, the interpretation of the phenomenon studied was sought from a perspective of dialectical comprehension, in an attempt to identify the educational propositions and the various aspects that compose this dynamic. The problematization of the reality and the adopted theoretical framework permitted the proposal of three categories of analysis for the interpretation of the empirical data: - the educational process - understood as work endowed with object, purpose, means and instruments to obtain a given result. This work process uses - the critical concept of education - education committed to the critical interpretation of reality from the perspective of the transformation of social inequalities and the emancipation of the coparticipant subjects of the educational action and interdisciplinarity - as a condition or means to meet the integrality of healthcare of the individuals and social groups from the perspective of collective health, through the educational approach.

The research project met all the ethical precepts, having been approved by the Research Ethics Committee of the College of Nursing, University of São Paulo. The four HEIs, representing the public and private spheres, were selected according to criteria of: social exemplarity, technical and scientific skills, capacity for insertion and expansion in the private market. The authorization to conduct the research was obtained from the Director, in one of the institutions, and from the Coordinators of the Courses in the others.

The collection of the empirical data occurred through documental analysis of the Political Pedagogic Project (PPP) of the courses, of the curricular proposals (syllabi, proposals, frameworks) and of semi-structured interviews according to a script, directed toward the teachers involved with the teaching of the thematic who were identified by the coordinators of the Courses and Departments, who were individually informed agreed to participate in the study and signed the Terms of Free Prior Informed Consent (TFPIC). A total of thirteen teachers were included. The interviews were conducted by the researcher in the period from April to October 2008, the data was transcribed and subjected to exhaustive reading which allowed the identification of thematic nuclei. The research script consisted of identification and socio-demographic data, 
professional profile, strategies to address the function of teacher, the concept of education, which were based on the contents and the strategies adopted, the profile of the graduate formed and the contributions of the teaching to the educative thematic. The documental and data analysis obtained in the field research followed the steps of content analysis ${ }^{(19)}$. This started from the theoretical and methodological framework of nursing in $\mathrm{CH}$ constructed by the authors ${ }^{(9)}$, whose contribution, based on the educative process analytical category, allowed the identification of the empirical categories that were expressed, respectively, by the themes - Agent of the educative process; Potentialities of nursing; The intentionality of the actions in the curricular organization; The working conditions; The social practice performed; and the sub-themes - Profile of the teachers; Professional trajectories; Proximity of nurse-patient-citizen relationship and the bond created; Expanded comprehension of the subject; Definition of care as the guiding axis of the actions; Concept of education adopted; Strategies used; Articulation of content; Integration between theory and practice; Difficulty in comprehending the social practice of the Teacher; Deficit in the basic education of the students; Lack of coordination between the disciplines; Profile of the undergraduate student; Gain of the teacher.

\section{Results}

The study subjects constituted a group predominantly female, married, who self-declared themselves to be white, with doctorates, who recognized the need for education to perform the function of teacher and sought this education on their own initiative. Three professional trajectories were constructed by the subjects: those who have dedicated themselves to education; those who consolidated the practice as a nurse and later became teachers; and those who constructed the two practices simultaneously. The education in Public Health seems to ensure a special condition in relation to the other specializations. The majority also had the understanding that nursing has a greater or different potentiality for the development of educational action. The justifications cited were the proximity of the nursepatient-citizen relationship and the bond created, and the expanded perception of the subject of educational action, as well as the care process, guided by the holistic framework and the recognition of the care as the guiding axis of the Nursing actions.

In seeking to know how, in each of the HEIs, the teaching of health education to undergraduate students was organized, the following were identified: EI1 the concept of health promotion was configured as something which changed the theoretical content; the teachers cited Paulo Freire as the name of reference for the concept of education adopted; a relationship between the theoretical and practical proposals, due to the efforts and experiences of the professionals, was identified. The strategies adopted were seminars and educational projects to address problems such as drug use, violence, STDs, and sexuality. For teachers, the student learns the role of educator in any scenario of professional practice. EI2 - The contents are approached in order to respond to the specificities of at least four disciplines, from the concept of the thematic as a work process, in which the object comprises the individual with health problems and the proposed healthcare, the need for information to interpret the social context and the social groups, as well as the educative necessities of the workers. The educational action was developed through the elaboration of projects focused on the individual or the collective - of the popular education type or directed to the workers. Integration was established between the theoretical content and the practice. The efforts were noted of the teachers to form a more socially engaged and ethical professional, a holder of great respect for human diversity, with discernment of the social, cultural and epidemiological reality of a given area, as well as expressing knowledge of the system in which they act. Despite the effort, there was a perception that the profile obtained is still not the one desired. EI3 - The contents are defined following different concepts: from the framework of the cognitive behavioral approach, the model of beliefs, the concept of empowerment and self-efficacy, all elements of the behavioral theories of Psychology; there were those who linked the contents to the broader social context and to their determinants, seeking the reading, the problematization of the reality and the elaboration of the proposal(s) of intervention, grounded in the aspect of the new promotion of health and in the community empowerment; there were those who discussed the thematic as an instrumental inherent in the care work process, based on ethical values of respect, welcome, reflection, focusing on the autonomy of the families to decide, referenced by Rogers and Paulo Freire and others, who based themselves in expanded healthcare practice, focusing on the cultural context and on the concepts of alterity and of resilience. Integration was found between the theoretical and practical content, and a nonexistence of articulation between the disciplines. Among the teachers there were those 
who did not perceive the profile of nurse educator as a result of their work. The others identified the profile of a professional with technical and clinical competence, more mature, more sensitive to the social problematic of the population and stimulated for the development of scientific research. EI4 - The curriculum is integrated, organized by pedagogical cycles, maintaining close links with the social reality and the professional practice, so that the approximations, pedagogically organized to interpret these realities, are the proponents of the contents to be developed. The reality constituted the starting point for the theorization and for the development of the professional identity, recognizing the SUS as the project guide of this education. The result of this work has sought to contribute to the construction of experiences of the undergraduate students that make them conscious of the social dynamics of a given area, they recognize the needs of the individuals and of the collective, they comprehend the proposals of the political project of the sector - the SUS - the integrality of the care and the obligation to continue the study.

Some interviewees reported that: they do not usually cite the names of the authors used as references; the deficiency of basic education of the students, the immaturity of many, and little interest in political issues are perceived as hindering the development of educational work. Regardless of the particular professional trajectory the craft of teaching has produced a positive surplus for the agents of action, and is dynamic and rewarding work, which puts them in contact with the reality.

\section{Discussion}

Teaching - the educational process - is non-material work, which takes as the object of transformation the thoughts, values and demands that the education professional is in a constant process of updating, in view of the knowledge produced by humanity. The initial and continuing education of these teachers is the responsibility of the Educational Institutions, in order that they may comprehend the significance of the teaching practice ${ }^{(20)}$. Health education is intended to perform a role in the control of diseases or of the at risk populations ${ }^{(21)}$. Thus, the predominant educational focus was the preventive, under the hegemony of the culture of biosociality - expressed by the excessive valorization of the healthy body and of the biological parameters(22). The focus of informed choice, of the personal development and the radical approach were cited by the study subjects. The focus of Popular Education was cited, but not as a political action, reaffirming the difficulty to operationalize it in health services. It was found that the concept of Health Promotion was mentioned, without, however, being possible to perceive in the majority of the discourses the differences and conceptual implications in the predominant practices - the Behaviorist and the New Promotion of Health ${ }^{(23)}$. In the multiple references to Paulo Freire it was perceived that the humanistic principles of the author are being used by the teachers and learned by the students, without the necessary articulation with the political references of the educator, in a manner detached from a project of society and from the conflicts inherent to the interests in dispute. The educational strategies were extremely diverse, occurring both in the health facilities and in the community spaces, having been developed with other courses and even in partnership with other Departments. In some situations, there was a preference for the practical approach and the simplification of the theoretical content, resulting in the 'instrumental approach' of the educational process, a theory-practice and technical-political disarticulation, both for the students and the teachers, devaluing the political dimension of this process. The curricular changes have brought about a level of disciplinary articulation indicative of curricular interdisciplinarity and in the EI, where the curriculum is integrated, pedagogic interdisciplinarity seems to exist, in which agents in interdisciplinary attitude are committed to the construction of new knowledge, with a view toward the solidification of a cohesive educational project(24).

Regarding the potentiality of nursing to develop educational actions, the results determined in the holistic framework, directly influenced by the productions of Wanda de Aguiar Horta, affiliated to the general systems theory and the relationship and responses of human behavior, even though it represented a broader comprehension of the health-disease phenomenon, still shows itself constrained to interpret the process of life and the other determinations originating from social totality, since it reduces the analysis to the individual dimension, to the psychological and hides the conflicts existent in society, in the health care practice and even within the practice of nursing(25).

\section{Conclusions}

The teaching of health education in the nursing courses of the State of São Paulo has been performed by a group consisting mainly of women, whose professional qualification prove solid in the sense of lato 
sensu and stricto sensu qualifications, in accordance with the requirements of the National Higher Education Assessment System (SINAES) and they also reaffirmed the need for education for the task of teaching. However, it was observed that in the context of the neoliberal ideas, which changed the role of the university and invested in the expansionist policies of the private sector, the qualification requisites of the faculty are contributing to the lighter education of teachers, once again compromising the quality of the education offered directly to the students, and, indirectly, the provision of services offered to the population. The comprehension of this formation from the concept of the educational praxis is based on two central elements - thought and action. In this sense, this process is initiated in the schools, when the teacher is still a student, and extends throughout the career, in a process of constant improvement.

In the area of nursing, the importance attributed to a political preparation for this role can be observed. Although efforts are being undertaken to overcome the education of the nurse teacher consolidated in the technical rationality, it can be observed that there is greater availability of education courses specific to the area of actuation (technical), subordinating the pedagogical aspects and the socio-political themes. This context tends to feed-back the profile of the profession highlighted by the excellence in technical capability and by the impoverishment in political action. The absence of the political dimension in the educational process contributes to the development of a conservative educator, devoid of a transformative perspective, whose purpose is the instrumentalization of the subjects to interpret the world in which they live and become ill. The conditions in which this process is developed are associated with this scenario, characterizing what has been called the instrumental approach, sometimes represented by the deficiency of basic education of the students, sometimes by the difficulty of the teachers in articulating the content of the various disciplines, benefiting from the expanded vision of Public Health, to analyze the theoretical components of the propositions of care intervention or even the context that involved the NCG.

Given the contemporary context of assumption of the HEIs of the restrictive role of social rights, it is essential that the subjects, in the full exercise of their citizenship, seek articulation with other subjects, promoting the connection with the policy makers and with other social institutions, in the solidification of a transforming education, which links to the other processes and social projects that will contribute to social changes, constructed towards a just and moderate society, and to the public and universal system of health proposed.

\section{References}

1. Mendes MMR. O ensino de graduação em enfermagem no Brasil, entre 1972 e 1994 - mudança de paradigma curricular? [tese]. Ribeirão Preto: Escola de Enfermagem de Ribeirão Preto/USP; 1996. 312 p.

2. Germano RM. O ensino de enfermagem em tempos de mudança. Rev Bras Enferm. 2003; 56(4):365-8.

3. Ministério da Educação (BR). Conselho Nacional de Educação. Resolução n.o 3, de 7 de novembro de 2001: Institui Diretrizes Curriculares Nacionais do Curso de Graduação em Enfermagem. Diário Oficial da União, Brasília, 9 nov. 2001. Seção 1, p.37-8.

4. Melo JAC. Educação Sanitária: uma visão crítica. Cad CEDES. $1987 ;(4): 28-43$.

5. Wendhausen Á. Educação em saúde: possibilidades de uma proposta [dissertação]. Santa Catarina Florianópolis: Escola de Enfermagem da Universidade Federal de Santa Catarina;1992. 146 p.

6. Gonzaga FRSR. Para além do cotidiano: reflexões acerca do processo de trabalho de educação em saúde [dissertação]. Santa Catarina Florianópolis: Escola de Enfermagem da Universidade Federal de Santa Catarina; 1992. $132 \mathrm{p}$.

7. Wendhausen A, Saupe R. Concepções de educação em saúde e a estratégia de saúde da família. Texto Contexto Enferm. 2003;12(1):17-25.

8. Budó MLD, Saupe R. Conhecimentos populares e educação em saúde na formação do enfermeiro. Rev Bras Enferm. 2004;57(2):165-9.

9. Pereira E, Soares CB, Campos CMS. Proposal to construct the operational base of the educative work process in collective health. Rev. Latino-Am. Enfermagem. [internet]. 2007. [acesso em: 25 fevereiro 2010];15(6):1072-9. Disponível em: http://www. scielo.br/scielo.php?script=sci_arttext\&pid=S0104$1692007000600003 \&$ Ing=pt. doi: 10.1590/S010411692007000600003.

10. Abrahão AL, Garcia ALS. Sobre o exercício da educação em saúde: um estudo bibliográfico da prática de enfermagem. Ciênc Saúde Colet. 2009;7(31):155-62.

11. Chauí M. A universidade operacional. Folha de São Paulo. 09 mai. 1999; Caderno Mais: 3.

12. Bagnato MHS, Rodrigues RM. Diretrizes Curriculares da Graduação de Enfermagem: pensando contextos, mudanças e perspectivas. Rev Bras Enferm. 2007;60(5):507-12. 
13. Pinto AV. Ciência e existência. 3. ed. Rio de Janeiro:

Paz e Terra; 1979. 537 p.

14. Paim J, Almeida N Filho. Saúde Coletiva: uma "nova saúde pública" ou campo aberto a novos paradigmas: Rev Saúde Pública. 1998; 32(4):299-316.

15. Queiroz VM, Salum MJL. Reconstruindo a intervenção da enfermagem em Saúde Coletiva. In: Livro Programa - Livro Resumo do $48^{\circ}$ Congresso Brasileiro de Enfermagem; 1996. 6-11 out; São Paulo. São Paulo: ABEn - Seção SP; 1996. 361 p.

16. Vasquez AS. Filosofia da práxis. $2^{\mathrm{a} e d .}$ Rio de Janeiro: Paz e Terra; 1977. 453 p.

17. Trivinos ANS. Introdução à pesquisa em ciências sociais: a pesquisa qualitativa em educação. São Paulo: Atlas; $1987.176 \mathrm{p}$.

18. Minayo MCS. O Desafio do conhecimento pesquisa qualitativa em saúde. 5.ed. São Paulo: Hucitec-Abrasco; 1998. 269 p.

19. Bardin L. Análise de conteúdo. Lisboa: Presses Universitaires de France; Edições 70; 1977. 226 p.

20. Basso IS. Significado e sentido do trabalho docente. Cad CEDES. [internet]. 1998. [acesso $25 \mathrm{fev}$ 2010];19(44):19-32. Disponível em: <http://www. scielo.br/scielo.php?script $=$ sci_arttext\&pid $=$ S010132621998000100003\&lng=en\&nrm=iso >.

21. Stotz EN. A evolução histórica da educação e saúde, seus fundamentos e as mudanças individuais e coletivas analisadas a partir de um olhar do autor sobre o valor social da saúde. In: Ministério da Saúde (BR). Secretaria de Gestão Estratégica e Participativa. Departamento de Apoio à Gestão Participativa. Caderno de educação popular e saúde. Brasília: Ministério da Saúde; 2007. p. 46-57.

22. Ortega F. Biopolíticas da saúde: reflexões a partir de Michel Foucault, Agnes Heller e Hannah Arendt. Interface (Botucatu) [internet]. 2004. [acesso 25 fev 2010]; 8(14):9-20. Disponível em: http://www. scielo.br/scielo.php?script $=$ sci_arttext\&pid $=$ S141432832004000100002\&lng=en. doi: 10.1590/S141432832004000100002.

23. Carvalho SR. Saúde coletiva e promoção da saúde: sujeito e mudança. 2.ed. São Paulo: Hucitec; 2007. $183 \mathrm{p}$.

24. Maheu CA. Interdisciplinaridade e mediação pedagógica [internet]. 2009. [acesso 11 nov 2009]. Salvador: Universidade de Salvador, NUPEPEAD; Disponível em: http://www.nuppead.unifacs.br/artigos/ Interdisciplinaridade.pdf .

25. Almeida MCP, Rocha JSY. O saber de enfermagem e sua dimensão prática. 2.ed. São Paulo: Cortez; 1989. $128 \mathrm{p}$. 